\title{
ПРАВОВА СИСТЕМА: ВІД ТЕОРІЇ ДО ПРАГМАТИКИ
}

\section{Оніщенко Н. М., Тарахонич Т. I.}

\section{ВСТУП}

Проблематика правової системи входить у широкий науковий обіг із 80$\mathrm{x}$ pp. XX ст. Із цього моменту вказана категорія піддається суттєвому аналізу, вивченню, узагальненню та, відповідно, правовій аналітиці. Правова система вивчається у вітчизняній юридичній думці як феномен соціальної дійсності ${ }^{1}$, як категорія, генетично пов'язана 3 категорією «правова держава» ${ }^{2}$. Органічна єдність правової, соціальної та демократичної держави у фокусі національної правової системи досліджується провідними вченими ${ }^{3}$. Національні правові системи, механізм їх зближення та взаємодії неодноразово аналізувалися в юридичній науці ${ }^{4}$. Крім того, джерельне право різних правових систем ретельно вивчалося сучасними вченими ${ }^{5}$.

Безумовно, доленосним питанням в означеному форматі є дослідження контексту взаємодії i, головне, взаємозумовленості розвитку правової системи й активного, зрілого громадянського суспільства, що, на жаль, не було предметно вивчено у юридичній науці.

Правова система конкретного суспільства, відображаючи його соціально-економічну, політичну i культурну своєрідність, визначає цілісність, відображає єдність суспільства і є одним із виявів державного суверенітету держави, показником сталого правового розвитку. Вчені вважають, що національна правова система визначає своєрідність правового життя певного суспільства. Отже, цілком зрозуміло, що правова система як втілення відповідного досягнутого рівня розвитку права повинна бути здатною на: а) виконання певних завдань; б) відтворення

\footnotetext{
${ }^{1}$ Вступ до теорії правових систем : монографія / за заг. ред. О.В. Зайчука, Н.М. Оніщенко. Київ : Видавництво «Юридична думка», 2006. 432 с.; Правові системи сучасності : навчальний посібник / відп. ред. Ю.С. Шемшученко. Київ : Вид-во «Юридична думка», 2012. 492 с.

2 Заєць А.П. Правова держава в контексті новітнього українського досвіду : монографія. Київ : Парламентське видавництво, 1999. 248 с.

${ }^{3}$ Теорія держави і права : підручник / О.В. Петришин та ін. ; за ред. О.В. Петришина. Харків : Право, $2015.368 \mathrm{c}$

${ }^{4}$ Кресін О.В. Становлення теоретичних засад порівняльно-правових досліджень у другій половині XVIII - першій третині XIX століття: компаративна концептуалізація : монографія. Київ : Інститут держави і права ім. В.М. Корецького НАН України; Видавництво «Логос», 2017. 680 с.

5 Пархоменко Н.М. Джерела права: проблеми теорії та методології : монографія. Київ : ТОВ «Видавництво «Юридична думка», 2008. 336 с.
} 
необхідних у певних просторово-часових вимірах функцій; в) забезпечення необхідних умов ефективного правового регулювання.

Насамперед розглянемо деякі з невідкладних завдань сучасного етапу розвитку правової системи Украйни. Так, правова система України сьогодні повинна спрямовуватися на розбудову сучасної європейської держави. Проте, на жаль, напрацювання, рекомендації, вироблені в теорії державотворення, часто не спрацьовують на практиці.

Здавалося б, усе зрозуміло: курс визначений - ідеться про побудову демократичної, правової, соціальної держави з європейськими стандартами та взірцями захисту прав, свобод і законних інтересів людини. Отже, закономірним є питання функціональної здатності правової системи в контексті означених процесів.

Таким чином, спробуємо зупинитися на певному векторі або аспекті взаємоузгодженості та взаємовідповідності теорії та практики державотворення.

\section{1. Правова система демократичної, правової соціальної держави}

За сучасних умов зростає соціальна спрямованість правової системи як засобу формування і реалізації інтересів суб'єктів шляхом закріплення певних цілей, норм, правил поведінки.

Отже, суттєвою складовою частиною, яка відіграє пріоритетну роль у сучасних правотворчих і державотворчих процесах, $є$ забезпечення і захист прав людини. Проте нам здається, що говорити слід не тільки і не стільки про потенційно надані права, скільки про реальність їх використання, виконання, дотримання, застосування, а отже, «реалістичність» втілення в життя.

Більш того, від ефективного впровадження і реалізації настанов конструктивного права залежатиме виконання демократичною, правовою, європейською державою ролі соціального арбітра, «улаштовувача справ багатьох», здатність знімати соціальну напругу, уникати гострих соціальних конфліктів тощо.

Сучасні вчені-правознавці неодноразово зверталися до розгляду певних можливостей, які «відтворюють» переведення потенційних проголошених прав у реальну практичну площину.

Слід зазначити, що інколи для реалізації певного права необхідні, принаймні, не одна, а декілька можливостей, наприклад, економічні, освітні, соціальні, гендерні тощо, які існують у відповідному просторовочасовому континуумі. Беззаперечною $є$ теза, що другорядних або не першого гатунку прав людини не буває, тому кожне нереалізоване, не вчасно реалізоване або не повністю реалізоване право має своїм 
підгрунтям відсутність, насамперед, відповідних реально наявних можливостей.

Національна правова система поступово перетворюється на один iз важливих засобів забезпечення оптимальної єдності політичної та соціальної стабільності та динамізму, збереження цілісності суспільства, взаємодії особистісного і суспільного, правового та публічного чинників, які завжди перебувають у відносинах антиномії, тобто взаємопроникнення і внутрішньої суперечливості.

Правова система сочіальної, правової держави покликана: 1) забезпечити встановлену соціальною політикою стабільність громадянської згоди шляхом проголошення, реалізації й охорони соціально-правових умов для стимулювання активної частини населення на продуктивну працю як основу особистого добробуту; 2) підтримання оптимального співвідношення між прибутками працездатної частини суспільства та непрацездатними громадянами; 3) надання адресної соціальної підтримки учасникам АТО, членам їх сімей, дітям-інвалідам, дітям, позбавленим батьківського піклування, дітям-сиротам, іншим дискримінованим групам; 4) скорочення й обмеження масштабів зубожіння; стримування безробіття; 5) забезпечення прожиткового мінімуму громадян як однієї 3 умов розвитку зрілого, активного громадянського суспільства ${ }^{6}$.

Завдання правової системи в умовах демократичної соціально-правової держави зазнають впливу соціально-економічних, політико-моральних, етнонаціональних чинників. Зростає їх соціальний зміст, спрямований на зміцнення групової, міжгрупової, соціальної взаємодії людей із приводу реалізації своїх інтересів. Зазначені функції покликані забезпечувати існування, добробут, а інколи - і виживання самого суспільства, реалізацію прав і свобод людини і громадянина ${ }^{7}$.

Суттєвий вплив на функціонування правової системи здійснюють такі загальносоціальні завдання, як гарантування: а) національної безпеки, боротьби 3 агресією 3 боку РФ, ліквідації іiі наслідків, б) соціальних програм, спрямованих на підтримання охорони здоров'я, соціальне забезпечення непрацездатних тощо, захист та охорону прав дитини ${ }^{8}$.

Правова система сприяє вирішенню етнонаціональних завдань, поставлених перед суспільством, які спрямовані на збереження і розвиток

\footnotetext{
${ }^{6}$ Соціальна політика: вимоги суспільства, виклики часу, потреби людини : науково-аналітична доповідь / Ю.С. Шемшученко та ін. Київ : Ін-т держави і права ім. В.М. Корецького НАН України, 2016. 80 с.

${ }^{7}$ Bioprawo. Filozofia prawa w putaniach i odpowiedziach / pod red. Gezrego Zajadto i Kamila Zeidlero. Warzszawa : Kehexisnexis. 2013. P. 149-156.

8 Концепція забезпечення і захисту прав дитини в Україні. Київ : Ін-т держави і права ім. В.М. Корецького НАН України, 2013. С. 56-85.
} 
традицій, самого існування національної культури, мови, самобутності та відтворення етносу, виховання громадянської позиції.

Значний вплив на завдання правової системи справляє науковотехнічний розвиток усієї цивілізації. Держава повинна підтримувати науку, освіту, культуру, використовувати їх результати, сприяти розвитку i забезпеченню інтелектуального потенціалу суспільства, гарантувати інтелектуальний розвиток кожної особистості 9 .

Одночасно вона вживає запобіжних заходів щодо обмеження небезпеки, яка виникає від неконтрольованої появи та використання сучасних науково-технічних досягнень.

У цьому контексті важливим є використання європейського досвіду. Зокрема, право на цілісність особи - нове особистісне право, необхідність якого зумовлена науково-технічним прогресом, особливо в сфері людини i біологічної науки (т. 2 Хартії Європейського Союзу про основні права 2000 p.).

Роль правової системи в умовах сучасної держави визначається також необхідністю забезпечення самовизначення особи, iï розвитку та соціалізації. Право виступає як об'єктивно можливий масштаб соціальної свободи, що стимулює творчу активність, самосвідомість людини, гарантує визнання суспільством того, що кожний індивід народжується вільним і рівним з іншими, а верховенство права розглядається як соціальний феномен, який зумовлює невід'ємні права людини i громадянина на свободу, рівність, справедливість, гідне життя, повагу та недоторканність ${ }^{10}$.

Це сприяє можливості реалізації інших прав і свобод людини та громадянина, дає підстави для висновку про неприпустимість їх скасування або будь-якого обмеження. Саме завдяки визнанню гідності людини визнаються «недоторканними і невідчужуваними права людини, в силу чого вони складають основу будь-якого суспільства, а також справедливості» ${ }^{11}$.

Основне завдання правової системи - створювати чітко визначену, нормативну, стабільну основу для всього комплексу суспільних відносин, у т. ч. і для їх динаміки.

В умовах демократичної, соціальної, правової держави, котра визначилася зі своїм європейським вибором, реалізується сфера правового регулювання, сукупність суспільних відносин, яку можливо і необхідно упорядковувати за допомогою права i правових засобів. Основним

\footnotetext{
${ }^{9}$ Тімуш І.С. Інтегральний погляд на право. Київ : Атіка, 2009. С. 165-174.

${ }^{10}$ Jolanta Jablonska-Bonca. Ontroletion to law. Warszawa : Lexis Nexis. 2008. P. 35.

${ }^{11}$ Грищук О.В. Людська гідність у праві: філософські проблеми. Київ : Атіка, 2007. 432 с.
} 
напрямом правового регулювання за цих умов $\epsilon$ : а) закріплення й охорона нових суспільних відносин; б) забезпечення сприятливих умов і засобів існування індивідів; в) реалізація і правовий захист життєво важливих потреб; г) інтересів людей і соціальних спільностей; д) заборона певних суспільних відносин i поведінки (заснування комерційних банків посадовими особами, робітниками правоохоронних органів їх родичами (активізація діяльності НАБУ, НАЗК, створення Вищого антикорупційного суду); е) стимулювання розвитку певних суспільних відносин; є) сприяння (за допомогою нових законів) виникненню i функціонуванню нових відносин i суспільних явищ, ж) розвиток правового світогляду й удосконалення правової ідеології.

Таким чином, важливе значення для проведення сучасних державних $\mathrm{i}$ правових реформ відіграють функції, притаманні правовій системі як явищу соціальної дійсності.

Наукове дослідження правової системи передбачає вивчення не тільки іiі статики, а й динаміки, того, як вона функціонує, змінюється, як виконує своє соціальне призначення. Зрозуміло, що виділення статичних чи динамічних компонентів правової системи має суто теоретичний характер, адже вони перебувають у тісному взаємозв'язку і відокремлено, без взаємодії втрачають свої якісні характеристики.

Функціонування національної правової системи залежить від усієї сукупності суспільних відносин, економічних, політичних, соціальних i духовних чинників. Термін «функиіонування правової системи» відображає іiі дію в соціальній системі. Дати функціональну характеристику правової системи означає визначити й описати способи іiі дії, шляхи і форми впливу на суспільні відносини. Стабільність, динамізм і системність суспільних відносин $є$ необхідними умовами прогресу суспільства.

У цей період розвитку суспільства Україна потребує ефективної реалізації інтеграційної, організаційної, регулятивної, охоронної та інших функцій правової системи.

Функції правової системи в умовах демократичної, соціально-правової держави зазнають впливу соціально-економічних, політико-моральних, етнонаціональних чинників.

У соціально-економічній сфері національна правова система здійснює дві взаємопов'язані функції: 1) сприяє економічному розвитку i максимальній активності (зайнятості) населення; 2) забезпечує соціально новий рівень споживання, сприяючи сучасним уявленням про загальнолюдську гідність.

В умовах розвитку ринкових відносин особливого значення набуває функція правової системи щодо забезпечення соціальної захищеності 
населення, боротьби з безробіттям, розвитку соціального партнерства, створення надійних механізмів захисту прав і свобод людини i громадянина, впровадження гендерних правовідносин i ïx наукового тлумачення в контексті світових трансформацій.

Здійснення завдань і функцій демократичної, соціальної, правової держави передбачає створення i використання надійних юридичних механізмів реалізації свободи, рівності та справедливості з урахуванням неможливості існування абсолютної необмеженої свободи й абсолютної рівності. Ці механізми мають визначити оптимальне співвідношення державних, правових, економічних складників регулювання та саморегулювання суспільних процесів, регулювати також перерозподіл матеріальних ресурсів для забезпечення певного, наявного в державі рівня життя, сприяти зниженню соціальної напруги.

За допомогою механізму правового регулювання відносини між суб'єктами набувають певної правової форми. Саме через норми права держава встановлює міру можливої та дозволеної поведінки людей.

Регулятивна функиія національної правової системи соиіально-правової держсави спрямована на забезпечення взаємодії індивідуального i колективного, приватного і публічного чинників, які завжди перебувають у відносинах не тільки взаємозалежності, а й суперечливості, бо кожен із них окремо є потенційно внутрішньо суперечливим. Відомо, що не тільки права i публічні інтереси $\epsilon$ суперечливими за своєю соціальноідеологічною природою, будь-яка соціальна група, а загалом і суспільство, не $\epsilon$ однорідним за своїм складом та утворенням ${ }^{12}$.

Ринковий механізм виробництва здатний функціонувати лише за наявності стабільного правового простору соціально-економічних $\mathrm{i}$ політичних відносин.

Регулятивна функція правової системи демократичної, соціальноправової держави спрямована на два відносно самостійні, але взаємопов'язані явища - індивідуальні права, свободи та на публічні інтереси суспільства.

Одним із негативних наслідків реформ в Україні, що проводилися імпульсивно, без необхідного наукового обгрунтування, стало обвальне падіння виробництва, закриття та банкрутство підприємств, катастрофічне збільшення дефіциту бюджету, занепад соціальної сфери, внаслідок чого спостерігається масове зубожіння народу. У зв'язку з цим Україна сьогодні визначається як країна, де не захищені основоположні права.

\footnotetext{
12 Петришин О. До проблеми соціалізації юридичних знань. Про українське право. Часопис кафедри теорії та історії держави і права Київського нац. ун-ту імені Тараса Шевченка. 2010. Чис. IV. С. 53-63.
} 
Основні права мають передумовою свого існування, 3 одного боку, ефективність держави, яка їх гарантує і захищає, з іншого - баланс саме цієї держави та розвиненого громадянського суспільства.

На думку дослідників-державознавців, із цієї дилеми може бути тільки один висновок: провести тонке, диференційоване розмежування між сферою захисту основних прав i ïх обмеженням. Держава повинна захищати свободу індивіда за умови гарантування достатнього захисту публічних інтересів ${ }^{13}$.

Специфічною юридичною гарантією прав i свобод людини та громадянина $\epsilon$ ефективність функціонування, високий ступінь цілісності правової системи, в яку включений інститут прав людини ${ }^{14}$.

Проте нормативно-правові засоби забезпечення прав і свобод людини та громадянина самі по собі не можуть створювати фактичні умови для використання кожним своїх прав і свобод. Гарантування прав і свобод не може бути достатньо ефективним за відсутності належних соціальноекономічних, політичних, культурних та інших умов, які визначають дієвість, сутність, конструктив юридичного забезпечення прав і свобод особи.

Досвід розвинутих європейських країн свідчить, що в них відбувається постійний процес вдосконалення комплексу заходів правового, соціальноекономічного, політичного, організаційного і виховного характеру, метою яких є створення належних умов для реалізації, охорони і захисту прав i свобод особи в умовах функціонування впливового громадянського суспільства.

Розглянемо цю констатацію на цікавому, як нам видається, прикладі, а саме врахування ініціативи в праві в контексті громадянського активізму в процесі право-державозмін сьогодення.

Ініціатива в праві у нашому викладі пов'язується 3 представниками й осередками громадянського суспільства, представниками певних соціумів, професійних (корпоративних) груп, груп, сформованих за віковою ознакою чи за ознакою гендерної рівності, тощо. Тобто, суб'єктне коло носіїв ініціативи в праві може бути досить широким і не має сталого, константного вигляду. Ініціатива в праві може мати т. зв. «комбінований» характер, коли іiі відпрацьовують як представники доктрини, так i юристи-практики. Прикладом може слугувати інститут конституційної скарги, яка була запропонована до вивчення вченими - представниками правової доктрини А. Селівановим, П. Євграфовим, а також суддями Конституційного Суду України М. Гультаєм, В. Скоморохою, А. Головіним та ін.

\footnotetext{
13 Мартин Ван Кревельд. Расцвет и упадок государства / пер. с англ. ; под ред. Ю. Кузнецова, А. Макеева. Москва : ИРИСЭН, 2006. С. 482-499.

14 Лобойко Л., Шило О. Концепція судового права у контексті судового захисту прав і свобод. Право України. 2015. № 3. С. 60-70.
} 
На наш погляд, ініціативу в праві в загальному сенсі можна визначити як постановку питання про необхідність внесення змін і доповнень у чинні норми, скасування далеких із них або прийняття нових норм права задля більш ефективного регулювання суспільних відносин.

Хочемо також наголосити, що реальне забезпечення ініціативи в праві пов'язане 3 такими явищами, як громадянська вихованість, громадянська позиція, правова активність представників громадянського суспільства. «Якщо людина хоче, щоб iï особисті права були захищені, вона мусить усвідомити суспільне правове життя і брати в ньому участь» ${ }^{15}$.

На жаль, останнім часом все більше нарікань у суспільстві на неподолану корупцію, корупційні схеми, повільні реформи, порушення прав людини.

Втім, як нам видається, підгрунтям подолання перерахованих негативних явищ мають стати не тільки економічний чи соціальний чинники, але й власна громадянська позиція, власна спроможність давати відсіч негативним проявам нашого життя. Тобто, іншими словами, не очікування, що хтось прийде i «прибере все сміття» 3 твоєї власної домівки, а наполеглива, кропітка праця в усіх сферах життєдіяльності нашого суспільства. Багато в чому означена «спроможність» до особистих рішучих дій (саме дій, а не тільки нарікань) залежить від громадянського виховання, а отже, від громадянської вихованості, від бажання проявляти ініціативу в усіх сферах життя людини задля його покращення, особливо у сфері сучасного права, починаючи від особистої обізнаності 3 ним і завершуючи формуванням власної позиції з метою покращення праворегулюючих процесів.

Адже тільки особистість, вихована в ідеалах демократії, на найкращих взірцях розвиненого громадянського суспільства, людяності, порядності, високого служіння людству і відданості громадянській позиції, може стати гідним членом українського суспільства.

Сьогодні всім нам необхідне відродження поваги до права, принципу верховенства права, принципу правозаконності, підвищення авторитету громадської думки, формування та розвиток громадянської позиції (саме ці фактори i покладаються в «ініціативне» ставлення до чинного або бажаного права).

\section{2. Методологічний інструментарій правової системи}

Правову систему, без перебільшення, можна вважати багатогранним, комплексним, динамічним явищем, що має рівневий характер i функціональну спрямованість. Пізнати іiі сутнісні властивості, змістовне

15 Тимошенко В.І. Природна правосвідомість (з історії політичної правової думки). Бюлетень міністерства юстииії України. 2013. № 2. С. 80. 
наповнення, сформулювати концептуальні засади теорії правової системи можливо, використовуючи методологічний потенціал юридичної науки та конкретного наукового дослідження.

На думку вітчизняних вчених, методологія сучасної юридичної науки становить складне і багатопланове утворення, яке охоплює: проблеми структури наукового знання взагалі та наукових правових теорій зокрема; закони виникнення, функціонування і зміни наукових правових теорій; понятійний каркас юридичної науки та іiї окремих дисциплін; структуру методів юридичної науки; аналіз іiі наукової мови, формальних i формалізованих методів дослідження (методики і процедури дослідницької діяльності), типології систем наукового правового знання тощо ${ }^{16}$.

Структурно методологія юридичної науки включає логічно викладені та науково обгрунтовані підходи, що відображають світоглядну позицію вчених, сукупність загальних принципів і методів наукового пізнання та вчення про них у їх єдності та взаємозумовленості. Методологія у своїй основі об'єднує знання різних наук, де ключове місце належить філософсько-світоглядним підходам. Ця єдність є засобом суб'єктивного осмислення функціональних можливостей і закономірностей правової системи. Якщо говорити про рівневий характер методології, то вона може бути забезпечена інструментарієм, що належить до емпіричного чи теоретичного рівня наукового пізнання. Емпіричний рівень пізнання правової системи передбачай збір, аналіз інформації, виявлення подібних і відмінних рис правових систем, тоді як теоретичний рівень пізнання надає можливість виявити й охарактеризувати закономірності та загальні тенденції розвитку правових систем сучасності, виявити ті чинники, що впливають на зближення правових систем, тощо.

Методологічною основою загальнотеоретичного дослідження категорії «правова система» $\epsilon$ наукові підходи. $\mathrm{У}$ науковій літературі методологічний підхід визначають як побудовану на гранично загальних (філософських) категоріях світоглядну аксіоматичну ідею (засаду), яка постулює загальну стратегію дослідження, відбір досліджуваних фактів та інтерпретацію результатів дослідження ${ }^{17}$.

Філософсько-світоглядні підходи забезпечують грунтовну оцінку правової системи, спрямованість дослідження на отримання певного результату. Основні пізнавальні категорії філософії, такі як конкретне й абстрактне, явище та сутність, структура й елементи, загальне й окреме,

\footnotetext{
${ }^{16}$ Гусарєв С.Д., Тихомиров О.Д. Юридична деонтологія (Основи юридичної діяльності) : навчальний посібник. Київ : Знання, 2008. С. 63.

17 Рабінович П.М. Наука філософії права: до характеристики предмета й методології. Проблеми філософії права. Т. 1. Київ - Чернівці : Рута, 2003. С. 24.
} 
сприяють грунтовному аналізу правової системи, пізнанню іiі природи, змісту та сутності.

Водночас вітчизняні вчені наголошують на можливості поєднання методологічного потенціалу теорії права, філософії права та інших наук, підкреслюючи, що теорія права конкретизує, емпірично підтверджує й уточнює (або спростовує) виявлені філософією права «позаюридичні» закономірності та пропонує філософії права розгалужену систему юридичних понять i категорій, юридичних закономірностей права ${ }^{18}$. Це є яскравим проявом взаємодії та взаємопроникнення, використання знань і здобутків різних наук у процесі аналізу об'єкта пізнання, у цьому разі - правової системи.

Аналізуючи правову систему саме 3 феноменологічного підходу, охарактеризуємо ті особливості правової системи, які дозволяють зрозуміти їі сутнісне наповнення, ті закономірності, що ій властиві. Використовуючи саме феноменологічний підхід для характеристики правової системи, Д.В. Лук'янов підкреслює, що правова система - це сформована під впливом об'єктивних закономірностей розвитку певної соціальної спільноти сукупність усіх іiі правових явищ, які перебувають у стійких зв'язках між собою та 3 іншими соціальними системами. Та водночас вчений зазначає, що будь-яке визначення правової системи «<..> або не охоплює всіх характеристик останнього, або спрощує складне соціально-правове явище» ${ }^{19}$.

Заслуговує також на увагу порівняльно-правовий підхід, який широко використовується для аналізу правової системи. Характеризуючи такий підхід, науковці зауважують: по-перше, у межах самого порівняльноправового підходу може бути використана ціла сукупність, певна система методів, принципів, правил тощо; по-друге, у деяких випадках за допомогою переплетення порівняльно-правового підходу 3 іншими методологічними інструментами утворюються його різновиди, наприклад, порівняльно-логічний, порівняльно-історичний, порівняльно-типологічний тощо; по-третє, зміст i характер порівняльно-правових методів i дослідницьких процедур визначаються, виходячи 3 пріоритету порівняльно-правового підходу, який систематично застосовується ${ }^{20}$.

\footnotetext{
${ }_{18}^{18}$ Малишев Б.В. Правова система (телеологічний вимір) : монографія. Київ : «ВД «Дакор», 2012. С. 16.

19 Лук'янов Д.В. Правова система. Велика украйнська юридична енциклопедія : у 20 т. Харків : Право, 2016. Т. 3 / редкол. : О.В. Петришин (голова) та ін. ; Нац. акад. прав. наук України; Ін-т держави і права імені В.М. Корецького НАН України; Нац. юрид. ун-т імені Ярослава Мудрого. 2017. С. 497.

20 Дамірлі М.А. Методологія порівняльно-правових досліджень. Велика українська юридична енцииклопедія : у 20 т. Харків : Право, 2016. Т. 3 / редкол. : О.В. Петришин (голова) та ін. ; Нац. акад. прав. наук України; Ін-т держави і права імені В.М. Корецького НАН України; Нац. юрид. ун-т імені Ярослава Мудрого. 2017. С. 272.
} 
Важливе значення у процесі аналізу правової системи має системний підхід. Аналіз правових категорій із погляду системи грунтується на системних параметрах, серед яких виділяють стабільність системи, тобто здатність іiі структурних елементів зберігати власну структуру в процесі змін у самій системі; автономність системи, тобто можливість системи зберігати свою цілісність у процесі змін, які відбуваються 3 іiі структурними елементами ${ }^{21}$. Характеризуючи складники правової системи, варто говорити про системно-структурний підхід, що характеризує правову систему з погляду статики, водночас аналіз функціональної спрямованості компонентів правової системи надає можливість використовувати системно-функціональний підхід i свідчить про динамічність правової системи, функціонування іiі складників.

Поряд із системним підходом має місце цивілізаційний підхід, який сприяє аналізу різних правових систем сучасності, допомагає охарактеризувати їх спільні та відмінні риси, забезпечити можливості використання позитивних рис одних систем для найбільш оптимального функціонування інших систем. На думку Х. Бехруза, застосування цивілізаційного підходу передбачає інтерпретацію історичного процесу, різних культурних, соціальних, правових та інших явищ, з урахуванням особливостей і специфічних рис цивілізацій, що спричинили появу цих явищ ${ }^{22}$.

Аналізуючи герменевтичний підхід у праві, ряд вітчизняних вчених підкреслюють, що предметом герменевтики права охоплюється тлумачення концепту права, основних правових понять, норм права i юридичних фактів із метою 3'ясування їхнього сенсу ${ }^{23}$. Використання герменевтичного підходу сприяє об'єктивному аналізу правової системи шляхом інтерпретації тих категорій і понять, що є характерними для неї.

Л.Г. Матвєєва, аналізуючи транзитивність держави, звертає увагу на можливість існування транзитивної правової системи, для аналізу якої використовується підхід, що визначає правову систему суспільства 3 iї не тільки статичної, а й функціональної, динамічної сторони. Вчена зазначає, що в цьому плані продуктивним видається синергетичний підхід, у рамках якого правову систему можна розглядати не тільки як спосіб розташування елементів об'єкта в просторі, а й як темпоральну будову певного процесу, як послідовність і ритм зміни процесу ${ }^{24}$.

\footnotetext{
21 Дія права: інтегративний аспект : монографія / кол. авторів; відп. ред. Н.М. Оніщенко. Київ : Видавництво «Юридична думка», 2010. С. 149.

22 Бехруз Х. Цивілізаційний підхід як методологічна основа вивчення ісламського права. Право Украӥни. 2011. № 8. С. 168.

23 Дудченко В.В., Аракелян М.Р., Завальник В.В. Герменевтика права: розвиток юриспруденції : навчальний посібник. Одеса : Фенікс, 2014. С. 28.

${ }^{24}$ Матвєєва Л.Г. Транзитивність у правовій сфері : монографія. Київ : Юрінком Інтер, 2015. С. 48.
} 
Узагальнивши, слід підкреслити, що синтез наукових підходів дасть можливість охарактеризувати правову систему з різних сторін, створивши найбільш цілісне уявлення про особливості правової системи, виявити й охарактеризувати причинно-наслідкові зв'язки в процесі іiі еволюції. Виважене використання кожного із зазначених підходів сприятиме розв'язанню певного завдання, що зумовлено особливостями правової системи.

Важливе місце в аналізі правової системи відводиться методам наукового пізнання. У юридичній літературі метод розуміють як науково обгрунтовану та філософсько виправдану систему засобів пізнавальної діяльності, що відповідає природі права i пов'язана 3 предметом правознавства ${ }^{25}$; спосіб, шлях пізнання та практичного перетворення реальної дійсності, систему прийомів і принципів, що регулює практичну та пізнавальну діяльність суб'єктів ${ }^{26}$; упорядкований та організований спосіб діяльності, спрямований на досягнення певної практичної чи теоретичної мети ${ }^{27}$; тільки сукупність способів і засобів пізнання об'єкта ${ }^{28}$; специфічний спосіб наукового дослідження явищ i фактів державноправової дійсності ${ }^{29}$.

У цьому разі слід говорити про те, що в більшості наукових досліджень категорія «метод» аналізується через такі категорії, як «спосіб», «прийом», «засіб» чи їх сукупність, що $є$ науково виправданим, логічним і дозволяє глибше зрозуміти змістовне наповнення цієї категорії. Водночас наковці розрізняють ці категорії. 3 наведених положень випливає логічний висновок, що для аналізу правової системи використовується широке поле дослідницьких засобів, навіть тих, які застосовуються іншими науками, що

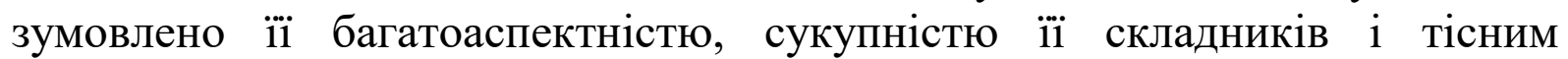
взаємозв'язком з об'єктивною реальністю. Зарубіжні вчені, підкреслюючи максимальну наближеність юридичної науки до реального життя, вказують, що таке «наближення» можливо здійснювати різноманітністю дослідницьких способів і засобів, вибір яких залежить від характеру та мети юридичного дослідження, філософського самовизначення та

\footnotetext{
${ }^{25}$ Методологія в праві : монографія / за заг. ред. І. Безклубого. Київ : Грамота, 2017. С. 103.

${ }^{26}$ Баскаков А.Я., Туленков Н.В. Методология научного исследования : учебное пособие. Київ : МАУП, 2002. С. 17.

${ }^{27}$ Рузавин Г.И. Методология научного познания : учебное пособие. Москва : ЮНИТИ - ДАНА, 2005. C. 4.

${ }^{28}$ Бобровник С.В. Компроміс і конфлікт у праві: антрополого-комунікативний підхід до аналізу : монографія. Київ : Вид-во «Юридична думка», 2011. С. 13-14.

29 Багай Н. До поняття юридичної науки. Вісник Львівського університету. Серія юридична. 2000. Вип. 35. С. 42.
} 
методологічного арсеналу дослідника як представника тієї чи іншої наукової школи чи традиції

Серед системи методів, які використовуються для характеристики правової системи, насамперед слід виокремити метод порівняння. Він займає чільне місце в аналізі різних правових систем, дає можливість виокремити й охарактеризувати як подібності, так i відмінності цих систем, закономірності та тенденції їх розвитку, ті причинно-наслідкові зв'язки, що між ними існують і впливають на процес їх зближення, на можливості використання позитивних рис одних систем для розвитку та вдосконалення інших тощо.

Застосування логіко-семантичного методу в дослідженні правової системи дозволяє звернути увагу на наукову термінологію, яка повинна бути загальновживаною, зрозумілою, змістовно наповненою. Досить часто в один і той самий термін вкладається різне значення. Так, наприклад, Н.М. Пархоменко, аналізуючи цей метод, зазначає, що «у романогерманській правовій сім'ї терміном «право», «джерела права» позначаються декілька понять, які відображають різні явища: справедливість, закон тощо. Причому право ототожнюється зі справедливістю, а закон розглядається як окремий термін. Це спричинило поширення природної концепції права. У Франції термін «право» і «закон» розмежовують (droin і loi), а справедливість і правосуддя ототожнюють із правильним, а не 3 правом. У Німеччині термінологічно розмежовують поняття «право» $\mathrm{i}$ «закон», а справедливість походить від права» ${ }^{31}$.

Метод правового моделювання використовується в процесі створення моделі правової системи. В енциклопедичній літературі підкреслюється, що загалом процес моделювання відзначається складною структурою i включає такі основні етапи: постановку проблеми, побудову моделі, iii дослідження, екстраполяцію отриманих результатів на оригінал ${ }^{32}$.

На першому етапі створення моделі правової системи необхідно визначити проблемну ситуацію, зібрати та проаналізувати інформацію, визначити мету та поставити завдання. Наступним кроком є створення самої моделі, в якій повинні бути відтворені структурні компоненти й особливості цієї моделі, що дозволить відтворити закономірності функціонування правової системи.

Цей метод пов'язаний із методом прогнозування. Прогностичний метод за допомогою наявної чи зібраної інформації дає можливість сформувати уявлення про перспективи, тенденції чи закономірності розвитку правових

\footnotetext{
30 Тарасов Н.Н. Метод и методологический поход в правоведении (попытка проблемного анализа). Правоведение. 2001. № 1 (234). С. 32.

31 Пархоменко Н.М. Джерела права: проблеми теорії та методології : монографія. Київ : ТОВ «Видавництво «Юридична думка»»), 2008. С. 30.

32 Філософський енциклопедичний словник / голова редкол. В.І. Шинкарук. Київ : Абрис, 2002. С. 392.
} 
систем. У зарубіжній літературі підкреслюється, що прогностичний метод - це комплексний метод, у якому інтегруються ряд методів (наприклад, метод систем, метод операцій і т.д.). Він характеризується рядом специфічних аспектів (способом, процесом, операцією, системою і т. п.), які відтворюють його зміст ${ }^{33}$.

У структурі методологічного інструментарію заслуговують на увагу також принципи наукового пізнання. В енциклопедичній літературі підкреслюється, що «принцип» походить від латинського principium начало, основа ${ }^{34}$.

Підкреслюючи базовий характер принципів наукового пізнання, звернемо увагу лише на ті, що найчастіше застосовуються для аналізу правової системи.

Принцип усебічності дозволяє охарактеризувати правову систему в єдності 3 іншими категоріями, явищами та процесами. Із принципом усебічності тісно пов'язаний принцип обгрунтованості, що сприяє аналізу правової системи з погляду законів формальної логіки, враховуючи об'єктивні умови ii функціонування та взаємозв'язок 3 іншими явищами та процесами. Принцип комплексності передбачає, що аналіз правової системи необхідно здійснювати крізь призму суміжних правових категорій, а саме механізму правового регулювання, системи права, права та ін. Принцип історичності надає можливість простежити етапність у формуванні правової системи, врахувати іiі національні особливості, традиції та самобутність.

Ряд вітчизняних вчених підкреслюють можливість використання принципу правового поліцентризму, підкреслюючи, що він передбачає врахування того, в межах якої правової сім’ї, правової цивілізації досліджуються правові та / чи державні явища (під правовою цивілізацією слід розуміти групу правових систем, що мають спільні релігійно-моральні та ідейно-філософські засади, подібні юридичні ознаки та споріднені соціокультурні, нормативно-ціннісні структури) і підхід до праворозуміння. Не викликає заперечень той факт, що в різних правових сім'ях не однакове розуміння права, а відтак і норм права, системи права, правовідносин, правомірної поведінки тощо, різні, серед них і правові цінності ${ }^{35}$.

Підсумовуючи, слід зазначити, що використання методологічного інструментарію сприяє об'єктивному аналізу правової системи, дозволяє виокремити й охарактеризувати особливості правових систем, їх закономірності та тенденції розвитку.

\footnotetext{
33 Сафаров Р.А. Прогностический метод государственного управления. Советское государство $и$ право. 1971. № 8. С. 75.

${ }^{34}$ Юридична енциклопедія : в 6 т. / редкол. : Ю.С. Шемшученко та ін. Київ : «Укр. енцикл.». Т. 5. 2003. C. $110-111$.

35 Кучук А.М. Правовий поліцентризм як принцип наукового пізнання правових явищ. Науковий вісник Ужггородського національного університету. 2013. Вип. 22. Ч. 1. Т. 1. С. 45.
} 


\section{ВИСНОВКИ}

1. Розвиток національної правової системи залежить (і це підкреслимо особливо) від багатьох чинників: економічних, соціальних, політичних, а також від особистої правової культури, правової свідомості, правового світогляду кожного представника громадянського суспільства, здатного самостійно мислити, приймати рішення, публічно висловлювати свою думку, нести відповідальність за наслідки своєї діяльності, проявляти зацікавленість у динамічному розвитку правової системи, в т. ч. шляхом прояву ініціативи в праві.

2. Національна правова система повинна забезпечити органічну єдність розвитку демократичної, соціальної, правової та європейської держави.

3. Розвиток національної правової системи передбачає створення i використання надійних юридичних механізмів у контексті розвитку ринкової економіки, створення гарантій розвитку виробництва; основними функціями правової системи $\epsilon$ регулятивна (закріплення реалій, що склалися в економіці) й охоронна (ефективна охорона відповідних правовідносин).

4. У фокусі європейського вектору розвитку прав людини розглядається явище громадянського активізму, зокрема його вплив на розвиток правової системи в процесі право-державозмін сьогодення.

5. Глобалізаційні та трансформаційні зміни в суспільстві та державі істотно вплинули на функціонування i розвиток правових систем сучасності, що вимагає нового рівня теоретичних узагальнень i використання якісного й ефективного методологічного потенціалу; застосування різноманітного методологічного інструментарію в процесі аналізу правової системи допомагає виявити ії сутнісні характеристики, ті проблеми, які існують, показати взаємозв'язок правової системи з іншими явищами та процесами та сприяє поглибленню наукового знання в цій сферi.

\section{АНОТАЦІЯ}

Представлена стаття присвячена сучасному етапу розвитку правової системи в контексті эї здатності до виконання певних завдань, відтворення необхідних у певних просторово-часових вимірах функцій, забезпечення необхідних вимог ефективного правового регулювання. Демократична правова система повинна дієво захищати права та свободи людини, відтворювати і впроваджувати принцип верховенства права, забезпечувати «якість» правового закону в національному законодавстві. Саме правова система повинна реалізувати положення про те, що людина $є$ найвищою соціальною цінністю. Якість європейської правової системи полягає у захисті загальнолюдських цінностей, культурних надбань, зокрема 
правокультурних. Слід зазначити, що в умовах демократичної правової держави відносини «особа - держава» зазнають суттєвих змін. Крім того, великого значення набувають сьогодні завдання з оптимізації правової системи, а отже, коригування іiі функцій. Зокрема, основне завдання правової системи - створювати чітко визначену, нормативну, стабільну основу для всього комплексу суспільних відносин, у т. ч. і для їх динаміки.

В умовах демократичної, соціальної, правової держави, яка визначилася зі своїм європейським вибором, реалізується сфера правового регулювання, сукупність суспільних відносин, яку можливо і необхідно упорядковувати за допомогою права і правових засобів. Використання методологічного інструментарію сприяє об'єктивному аналізу правової системи, дозволяє виокремити й охарактеризувати особливості правових систем, їх закономірності та тенденції розвитку.

\section{ЛІТЕРАТУРА}

1. Вступ до теорії правових систем : монографія / за заг. ред. О.В. Зайчука, Н.М. Оніщенко. Київ : Видавництво «Юридична думка», 2006. $432 \mathrm{c}$.

2. Правові системи сучасності : навчальний посібник / відп. ред. Ю.С. Шемшученко. Київ : Вид-во «Юридична думка», 2012. 492 с.

3. Заєць А.П. Правова держава в контексті новітнього українського досвіду : монографія. Київ : Парламентське видавництво, 1999. 248 с.

4. Теорія держави і права : підручник / О.В. Петришин та ін.; за ред. О.В. Петришина. Харків : Право, 2015. 368 с.

5. Кресін О.В. Становлення теоретичних засад порівняльно-правових досліджень у другій половині XVIII - першій третині XIX століття: компаративна концептуалізація : монографія. Київ : Інститут держави і права ім. В.М. Корецького НАН України; Видавництво «Логос», 2017. 680 с.

6. Пархоменко Н.М. Джерела права: проблеми теорії та методології : монографія. Київ : ТОВ «Видавництво «Юридична думка», 2008. 336 с.

7. Соціальна політика: вимоги суспільства, виклики часу, потреби людини : науково-аналітична доповідь / Ю.С. Шемшученко та ін. Київ : Інт держави і права ім. В.М. Корецького НАН України, 2016. 80 с.

8. Bioprawo. Filozofia prawa w putaniach i odpowiedziach / pod red. Gezrego Zajadto i Kamila Zeidlero. Warzszawa : Kehexisnexis, 2013. P. 149-156.

9. Концепція забезпечення і захисту прав дитини в Україні. Київ : Ін-т держави і права ім. В.М. Корецького НАН України, 2013. С. 56-85.

10. Тімуш I.C. Інтегральний погляд на право. Київ : Атіка, 2009. C. $165-174$. 
11. Jolanta Jablonska-Bonca. Ontroletion to law. Warszawa : Lexis Nexis, 2008. P. 35.

12. Грищук О.В. Людська гідність у праві: філософські проблеми. Київ : Атіка, 2007. 432 с.

13. Петришин О. До проблеми соціалізації юридичних знань. Про українське право. Часопис кафедри теорії та історії держави $і$ права Київського наи. ун-ту імені Тараса Шевченка. 2010. Чис. IV. С. 53-63.

14. Мартин Ван Кревельд. Расцвет и упадок государства / пер. с англ. ; под ред. Ю. Кузнецова, А. Макеева. Москва : ИРИСЭН, 2006. С. 482-499.

15. Лобойко Л., Шило О. Концепція судового права у контексті судового захисту прав і свобод. Право Украйни. 2015. № 3. С. 60-70.

16. Тимошенко B.I. Природна правосвідомість (з історії політичної правової думки). Бюлетень міністерства юстииї̈ Украӥни. 2013. № 2. С. 80.

17. Гусарєв С.Д., Тихомиров О.Д. Юридична деонтологія (Основи юридичної діяльності) : навчальний посібник. Київ : Знання, 2008. 497 с.

18. Рабінович П.М. Наука філософії права: до характеристики предмета й методології. Проблеми філософії права. Т. 1. Київ - Чернівці : Рута, 2003. C. $22-25$.

19. Малишев Б.В. Правова система (телеологічний вимір) : монографія. Київ : «ВД «Дакор», 2012. 364 с.

20. Лук'янов Д.В. Правова система. Велика украйнська юридична енциклопедія : у 20 т. Харків : Право, 2016. Т. 3 / редкол. : О.В. Петришин (голова) та ін. ; Нац. акад. прав. наук України; Ін-т держави і права імені В.М. Корецького НАН України; Нац. юрид. ун-т імені Ярослава Мудрого. 2017. 952 c.

21. Дамірлі М.А. Методологія порівняльно-правових досліджень. Велика українська юридична енциклопедія : у 20 т. Харків : Право, 2016. T. 3 / редкол. : О.В. Петришин (голова) та ін.; Нац. акад. прав. наук України; Ін-т держави і права імені В.М. Корецького НАН України; Нац. юрид. ун-т імені Ярослава Мудрого. 2017. 952 с.

22. Дія права: інтегративний аспект : монографія / кол. авторів; відп. ред. Н.М. Оніщенко. Київ : Видавництво «Юридична думка», 2010. 360 с.

23. Бехруз Х. Цивілізаційний підхід як методологічна основа вивчення ісламського права. Право Украӥни. 2011. № 8. С. 167-172.

24. Дудченко В.В., Аракелян М.Р., Завальник В.В. Герменевтика права: розвиток юриспруденції : навчальний посібник. Одеса : Фенікс, 2014. 184 с.

25. Матвєєва Л.Г. Транзитивність у правовій сфері : монографія. Київ : Юрінком Інтер, 2015. 328 c.

26. Методологія в праві : монографія / за заг. ред. І. Безклубого. Київ : Грамота, 2017. 658 с. 
27. Баскаков А.Я., Туленков Н.В. Методология научного исследования : учебное пособие. Київ : МАУП, 2002. 216 с.

28. Рузавин Г.И. Методология научного познания : учебное пособие. Москва : ЮНИТИ - ДАНА, 2005. 287 с.

29. Бобровник С.В. Компроміс i конфлікт у праві: антропологокомунікативний підхід до аналізу : монографія. Київ : Вид-во «Юридична думка», 2011. $384 \mathrm{c}$.

30. Багай Н. До поняття юридичної науки. Вісник Львівського університету. Серія юридична. 2000. Вип. 35. С. 38-44.

31. Тарасов Н.Н. Метод и методологический поход в правоведении (попытка проблемного анализа). Правоведение. 2001. № 1 (234). С. 31-50.

32. Пархоменко Н.М. Джерела права: проблеми теорії та методології : монографія. Київ : ТОВ «Видавництво «Юридична думка»», 2008. 336 с.

33. Філософський енциклопедичний словник / голова редкол. В.I. Шинкарук. Київ : Абрис, 2002. 744 с.

34. Сафаров Р.А. Прогностический метод государственного управления. Советское государство и право. 1971. № 8. С. 75-80.

35. Юридична енциклопедія : в 6 т. / редкол. : Ю.С. Шемшученко та ін. Київ : «Укр. енцикл.». Т. 5. 2003. 736 с.

36. Кучук А.М. Правовий поліцентризм як принцип наукового пізнання правових явищ. Науковий вісник Ужгородського національного університету. 2013. Вип. 22. Ч. 1. Т. 1. С. 43-46.

\section{Information about authors:} Onishchenko N. M.,

Doctor of Sciences (Law), Professor, Honoured Lawyer of Ukraine, Academician of the National Academy of Legal Sciences of Ukraine, Chief at the Department of Theory of State and Law of V. M. Koretsky Institute of State and Law of the National Academy of Sciences of Ukraine

4, Trjohsvjatitelska str., Kyiv, Ukraine

Tarakhonych T. I.,

Candidate of Law, Senior Researcher, Senior Researcher at the Department of Theory of State and Law of V. M. Koretsky Institute of State and Law of the National Academy of Sciences of Ukraine 4, Trjohsvjatitelska str., Kyiv, Ukraine 